\title{
The Impact of Hydrologic Characteristics of Mountain Watersheds on Geometric and Hydraulic Parameters of Natural Torrent Beds
}

\author{
Matúš Jakubis ${ }^{1 *}$, Mariana Jakubisová \\ 1 Department of Forest Harvesting, Logistics and Amelioration, Faculty of Forestry, Technical University in \\ Zvolen, UI. T. G. Masaryka 24, 96053 Zvolen, Slovak Republic \\ 2 Borova hora Arboretum of Technical University in Zvolen, Borovianska cesta 2171/66, \\ 96053 Zvolen, Slovak Republic \\ * Corresponding author e-mail: jakubis@tuzvo.sk
}

\begin{abstract}
The aim of the paper is to determine the geometric and hydraulic characteristics of natural torrent beds and to propose a regional hydraulic geometry equations of mountain watersheds for the High Tatras region. The research was conducted in 26 natural torrents and their watersheds on the reference sections and profiles under the sediment source zones. Two different regression equations to determine the relationships of hydraulic geometry (hitherto used without asymptote and newly proposed with asymptote) were compared. The analyses showed a strong correlation relationship between watershed area $\mathrm{A}_{\mathrm{w}}\left(\mathrm{km}^{2}\right)$ and bankfull geometric characteristics of natural crosssections: width of the bed inside the banks $B_{b f}(m)$, mean depth of the bed $H_{b f}(m)$, channel cross-section area $A_{b f}$ $\left(\mathrm{m}^{2}\right)$ and hydraulic characteristic - bankfull discharge $\mathrm{Q}_{\mathrm{bf}}\left(\mathrm{m}^{3} \cdot \mathrm{s}^{-1}\right)$. The results were tested by t-test and ShapiroWilk test. The determination coefficient $\left(\mathrm{R}^{2}\right)$ for the relationships without asymptote ranged between $\mathrm{R}^{2}=0.919$ and $R^{2}=0.972 ; p-$ values from Shapiro - Wilk test ranged between $p=0.0359$ and $p=0.8027$. The determination coefficient $\left(\mathrm{R}^{2}\right)$ for the relationships with asymptote ranged between $\mathrm{R}^{2}=0.952$ and $\mathrm{R}^{2}=0.974 ; \mathrm{p}-$ values from Shapiro - Wilk test ranged between $p=0.0221$ and $p=0.8617$. Based on the analysis we found that the new equation with the asymptote provides very good results.
\end{abstract}

Keywords: water balance equation; stream morphogenesis, High Tatras; Slovakia

\section{INTRODUCTION}

Out of the total length of the watercourses in the Slovak Republic (SR) stretching at 61,147 km, approximately $24,000 \mathrm{~km}(39.25 \%)$ are of a torrent nature. In the SR, the torrent watersheds are located in the protected areas (national parks, protected landscape areas). This fact must be taken into account in all interventions into torrent beds. Each torrent and watershed have a specific set of characteristics. There are several reasons for the acquisition of scientific knowledge in morphogenesis of torrent channels and regional hydraulic geometry of mountain watercourses and watersheds. The first is the possibility to use the results in practice (ecological torrent control, flood and erosion control, torrent revitalization, natural torrents management etc.). Developing hydraulic geometry relationships is of great importance for different applications of stream restoration design and hydrological modeling [Osati et al. 2016]. The second reason is the fact that this issue has not been adequately solved in the SR. Authors [Powel et al., 2004] indicate that in the USA are used in designing and revitalization of watercourses the regional equations of hydraulic geometry which are several decades old and are unsuited for existing conditions of water flows and watersheds. Author [Howell, 2009] suggests that regional hydraulic curves are especially useful in stream restoration projects where the stream is so degraded that natural bankfull channel geometry can no longer be determined and a reference reach is unavailable. Regional curves can also be used in 
project such as road, bridge and culvert construction. Another author [Wilkerson, 2008] states that this knowledge is essential for planners, engineers, geomorphologists, environmentalists, agricultural interests, developments situated on flood prone lands and other stakeholders in flooding and flood management. Regional curves should be applied only in projects within the same region or in the region with scientific evidence showing that it follows the same hydraulic geometry curves [Howell, 2009]. Physiographic region is a region with all parts similar in geologic structure and climate and with a unified geomorphic history [Wilkerson, 2008]. Its relief features differ significantly from those of adjacent regions. Another author [Leopold et al., 1992] states that there are two types of channel hydraulic geometry: at $-\mathrm{a}-$ station and downstream. Regional equations represents the relationships between geomorphologic and hydrologic characteristics of watershed and geometric and hydraulic characteristics of the channel profile. An important summary of regional hydraulic geometry research in the USA was published by another authors [Bieger et al., 2015] and [Blackburn - Lynch et al., 2017]. These authors dealed with the relations between the watershed area $\mathrm{A}_{\mathrm{w}}\left(\mathrm{km}^{2}\right)$ and bankfull geometric characteristics of natural cross-sections: the width of the bed inside the banks $B_{b f}(m)$, the mean depth of the bed $\mathrm{H}_{\mathrm{bf}}(\mathrm{m})$, the channel cross-section area $\mathrm{A}_{\mathrm{bf}}\left(\mathrm{m}^{2}\right)$ and hydraulic characteristic - the bankfull discharge $\mathrm{Q}_{\mathrm{bf}}\left(\mathrm{m}^{3} \cdot \mathrm{s}^{-1}\right)$. We point to few authors [Jakubis, 2008, Pšida, 2014] who were involved into the problem of relations between basic hydrologic characteristics of the watershed and the bankfull regional characteristics of natural torrent beds. This article discusses a new approach to the regional hydraulic geometry issues. The superstructure and the new current direction in the research of regional hydraulic geometry is the research of relations between the basic hydrologic characteristics of the watersheds: the mean longterm annual precipitation depth in the watershed $\mathrm{P}(\mathrm{mm})$, the mean long-term annual runoff depth in the watershed $\mathrm{Q}(\mathrm{mm})$ and the mean long-term annual climatic evaporation depth in the watershed $\mathrm{E}(\mathrm{mm})$ and the above mentioned geometric and hydraulic characteristics of the natural watercourse channels. he runoff generative process is highly variable and dependent on hydrologic and climatic characteristics of a watershed. The relations of runoff formation in small mountain watersheds were analyzed by the following authors in detail [Tani, 1997, Gallart et al., 2002, Hrnčír et al., 2010]. Precipitation is a prerequisite for runoff formation which depends on rainfall characteristics, initial moisture conditions, soil and geological conditions, vegetation, and topographic features [Han et al., 2012]. Surface runoff and later discharge in torrent channels has a significant impact on the long - term morphogenesis of torrent beds. Geometric characteristics of watercourse channels are created during longterm morphogenesis. In general, higher long-term precipitation sums in the watershed are a prerequisite for the higher runoff and consequently the for the higher discharge in torrent beds. In different natural conditions of the watersheds (hydrologic, climatic, geological, pedological, vegetation, morphology), characteristic of different physical geographic regions, exist in torrent beds specific geometric and hydraulic characteristics exist in torrent beds. There are certain regional specificities that manifest themselves in geometric and hydraulic characteristics of channels, their relations and ratios.

\section{MATERIALS AND METHODS}

Analyzed torrents and watersheds are located in the Tatras National Park (TNP) in the geomorphological unit of Tatry, the subunit of Východné Tatry, the part of High Tatras and the geomorphological unit of Podtatranská kotlina, the subunit of Tatranské predhorie (Figure 1) at altitudes from 860 to 2654 amsl. High Tatras are the highest mountains in the SR.

Between 2007 and 2017, twenty-six torrents with enclosing channel profiles near the southern border of TNP (near the northern border of the geomorphological unit of Podtatranská kotlina) were analyzed. Analyzed torrents are situated in two main river watersheds: Váh and Poprad. The watershed areas of 26 analyzed torrents range from $\mathrm{S}_{\mathrm{p}}=0.25 \mathrm{~km}^{2}$ (Važecký) to $\mathrm{S}_{\mathrm{p}}=19.34 \mathrm{~km}^{2}$ (Poprad) with the median $\mathrm{S}_{\mathrm{p}}=3.21 \mathrm{~km}^{2}$. The discharges $\mathrm{Q}_{100}$ range from $\mathrm{Q}_{100}=1.5 \mathrm{~m}^{3} \cdot \mathrm{s}^{-1}$ (Važecký) to $Q_{100}=35.7 \mathrm{~m}^{3} \cdot \mathrm{s}^{-1}$ (Biely Váh) with the median $\mathrm{Q}_{100}=10.25 \mathrm{~m}^{3} \cdot \mathrm{s}^{-1}$. The torrents of High Tatras are typical mountain torrents with frequent and rapid changes in discharges, sediments formation, transport of these sediments and their accumulation. Geological structure of analyzed area is complicated. In the High Tatras can be distinguished three main building 


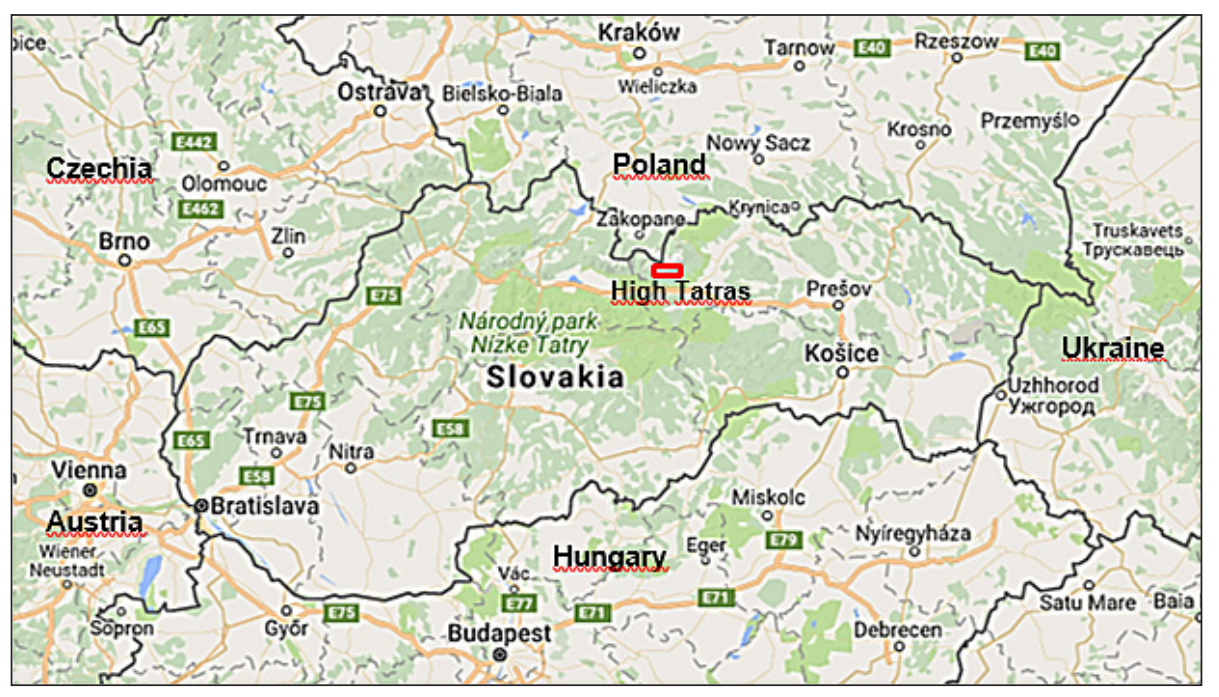

Figure 1. Map of Slovakia research area (High Tatras)

blocks: the crystalline core, mountain ranges and sedimentary cover and flysch fill adjacent depressions. Crystalline core occurs on a large part of the ridge and on the southern slopes of the mountains. In the higher parts of watersheds occurs migmatites - porphyritic granites and granodiorites. In the eastern part of the High Tatras, from the highest to middle position in a continuous strip occur porphyric granodiorites to granites, hercynian. In lower parts of analyzed watersheds forms the bedrock flysch - sandstones and calcareous claystones. From soil types are dominant in higher elevations Lithic Leptosols and others (nonrendzic) Leptosols, in lower positions Haplic Podzols to Humic Podzols. From the aspect of hydrological efficiency have the soils in the higher positions of watersheds high retention capacity with medium permeability and in the lower positions medium retention capacity and permeability [Composite Authors, 2002]. The watersheds (by the climatic regions of SR ) are located in climatic region $\mathrm{C}$ - cold subregions: $\mathrm{C} 1$ - moderately cool, $\mathrm{C} 2$ - cool mountainous and $\mathrm{C} 3$ - cold mountainous. The average annual precipitation in the watersheds range from $1037 \mathrm{~mm}$ (Pät' prameňov) to 1379 mm (Biely Váh). Average annual temperatures range from 0.9 to $3.8^{\circ} \mathrm{C}$.

From a methodological point of view is particurlary important the selection of reference sections and flow profiles and the determination of its geometric and hydraulic characteristics. In this regard, we follow the articles of authors [Page, 1988] and [Rosgen and Silvey, 1996]. In terrain under the source zones of torrents [Schumm, 1977, Lehotský and Novotný, 2004] were estabilished reference longitudinal sections (RLS) with reference cross sections (RCS). On the RCS were by leveling determined their geometric characteristic. Longitudinal slope was measured by levelung on RLS. On the RCS the sample of sediments was taken with weight at least $50 \mathrm{~kg}$ for granulometric analysis to determination of median grain diameter. Wetted perimeter and hydraulic radius were determined within the office processing.

To calculate bankfull discharge $\mathrm{Q}_{\mathrm{bf}}\left(\mathrm{m}^{3} \cdot \mathrm{s}^{-1}\right)$, we used the Equation according to Parker [2004]:

$$
\begin{gathered}
Q_{b f}=3.732 B_{b f} H_{b f} \sqrt{g R_{b f} S}\left(\frac{R_{b f}}{D_{50}}\right)^{0.2645} \\
\left(m^{3} s^{-1}\right)
\end{gathered}
$$

We used the following regression Equations for analysis:

- without asymptote

$$
\mathrm{y}=\mathrm{a}_{0} \cdot \mathrm{x}^{\mathrm{a} 01}
$$

- and with asymptote:

$$
y=a_{1} \cdot\left(1-e^{-k x}\right)+a_{11} \cdot x
$$

Equation (2) is generally used by many authors to estabilish hydraulic geometry relations. Equation (3) is a newly suggested means to the same end. Geometric and hydraulic characteristics of RCS are shown in Table 1.

In determination of basic elements of the water balance equation for all of the 26 analyzed 
Table 1. Characteristics of RCS

\begin{tabular}{|c|c|c|c|c|c|c|c|}
\hline Watercourse & $B_{b f}$ & $\mathrm{H}_{\mathrm{bf}}$ & $A_{b f}$ & $S$ & $\mathrm{R}_{\mathrm{bf}}$ & $\mathrm{D}_{50}$ & $Q_{b f}$ \\
\hline Beliansky & 3.7 & 0.65 & 2.0 & 2.85 & 0.435 & 0.141 & 4.22 \\
\hline Tri studničky & 0.9 & 0.35 & 0.3 & 2.10 & 0.214 & 0.105 & 0.30 \\
\hline Mlyničná voda & 2.9 & 0.55 & 1.2 & 2.77 & 0.364 & 0.091 & 2.70 \\
\hline Jamský & 1.0 & 0.40 & 0.4 & 3.55 & 0.267 & 0.090 & 0.61 \\
\hline Važecký & 0.8 & 0.30 & 0.2 & 2.90 & 0.154 & 0.077 & 0.24 \\
\hline Biely Váh & 7.2 & 0.80 & 4.9 & 2.37 & 0.620 & 0.123 & 12.53 \\
\hline Lieskovec & 2.0 & 0.40 & 0.7 & 3.90 & 0.292 & 0.152 & 1.19 \\
\hline Mlynica & 4.5 & 0.65 & 1.9 & 3.93 & 0.413 & 0.129 & 5.93 \\
\hline Poprad & 10.4 & 1.10 & 8.9 & 1.97 & 0.848 & 0.114 & 29.38 \\
\hline Vel'ký šum & 3.2 & 0.60 & 1.5 & 3.72 & 0.417 & 0.131 & 3.80 \\
\hline Malý šum & 1.9 & 0.50 & 1.0 & 2.31 & 0.417 & 0.135 & 1.47 \\
\hline Háganský & 1.0 & 0.30 & 0.3 & 3.70 & 0.188 & 0.091 & 0.35 \\
\hline Batizovský & 4.5 & 0.60 & 2.0 & 3.83 & 0.417 & 0.128 & 5.45 \\
\hline Hromadná voda & 2.7 & 0.50 & 1.1 & 4.20 & 0.355 & 0.093 & 2.75 \\
\hline Velický & 4.5 & 0.70 & 2.1 & 3.30 & 0.404 & 0.122 & 5.83 \\
\hline Slavkovský & 4.0 & 0.60 & 1.7 & 2.20 & 0.370 & 0.099 & 3.58 \\
\hline Malý Štiavnik & 1.9 & 0.45 & 0.8 & 0.85 & 0.308 & 0.060 & 0.79 \\
\hline Vel'ký Jazyk & 1.9 & 0.40 & 0.8 & 2.18 & 0.348 & 0.065 & 1.21 \\
\hline Štiavnik & 2.2 & 0.50 & 0.8 & 2.90 & 0.320 & 0.070 & 1.85 \\
\hline Pät' prameňov & 2.0 & 0.40 & 0.7 & 1.13 & 0.318 & 0.072 & 0.83 \\
\hline Pod Hrebienkom & 2.6 & 0.50 & 1.0 & 1.85 & 0.345 & 0.078 & 1.80 \\
\hline Studený & 9.8 & 1.10 & 7.3 & 2.63 & 0.716 & 0.400 & 20.16 \\
\hline Hlboký & 2.4 & 0.55 & 1.3 & 2.53 & 0.464 & 0.069 & 2.68 \\
\hline Skalnatý & 6.2 & 0.75 & 3.5 & 2.70 & 0.530 & 0.170 & 8.49 \\
\hline Kežm. Biela voda & 9.2 & 1.00 & 6.3 & 2.78 & 0.656 & 0.115 & 23.02 \\
\hline Sedem prameňov & 4.0 & 0.60 & 1.6 & 2.80 & 0.372 & 0.099 & 4.07 \\
\hline
\end{tabular}

Explanatory notes: $B_{b f}-$ width of the RCS inside the banks $[m], H_{b f}-$ mean depth of the RCS [m], $A_{b f}-$ RCS area $\left[\mathrm{m}^{2}\right], \mathrm{S}$ - energy gradient $[\mathrm{m} / \mathrm{m}], \mathrm{R}_{\mathrm{bf}}-$ hydraulic radius of RCS $[\mathrm{m}], \mathrm{D}_{50}-$ grain diameter $[\mathrm{m}], \mathrm{Q}_{\mathrm{bf}}-$ bankfull discharge $\left[\mathrm{m}^{3} / \mathrm{s}\right]$

watersheds of the High Tatras, the simplified relationship was used:

$$
P=Q+E \pm \Delta S
$$

where: $P$ - mean long-term annual precipitation depth in the watershed $(\mathrm{mm})$

$Q$ - mean long-term annual runoff depth in the watershed (mm)

$E$ - mean long-term annual climatic evaporation depth in the watershed ( $\mathrm{mm}$ )

$\Delta S$ - change in water storage in the watershed $(\mathrm{mm})$

Equation (4) is the simplest form of water balance equation valid only for long periods of time. It is used to calculate mean values of basic hydrologic characteristics for long periods of time. In this connection, our research proceeded from these basic assumptions:

- Thebasichydrological characteristics ofthewatershed indentified and evaluated in the longrun;
- development of torrent beds (torrent morphogenesis) is a long-time process of hundreds to thousands of years;

- component $\Delta \mathrm{S}$ in equation (4) is not considered in analyses, change of water retention in the watershed is negligible in a long-time process;

- from precipitation in the watershed is formed runoff and subsequently discharge in watercourse beds which has a dominant effect on their development (morphogenesis),

- long-term runoff $\mathrm{Q}$ expresses the runoff from the watershed in all forms;

- similar natural conditions in specific regions, mostly soil and geological, vegetation, topographic features, create similar conditions for the morphogenesis (long-term development) of torrent beds;

- regional hydraulic geometry equations can be developed from these results, having a broad practical application. 
To determine the elements of the equation (4), relationships was derived by authors [Szolgay et al., 1997]. The authors drew on the knowledge that the mean annual climatic evaporation depth $\mathrm{E}(\mathrm{mm})$ can be determined as a function of potential evaporation index $\mathrm{EP}_{\mathrm{i}}$ and of the mean longterm annual precipitation depth $\mathrm{P}(\mathrm{mm})$ :

$$
E . E P_{i}^{-1}=f\left(P . E P_{i}^{-1}\right)
$$

On the basis of the relation (4) and (5) and the data measured at 54 meteorological stations in the SR, authors [Szolgay et al., 1997] derived for the conditions of SR the following empirical relationships:

$$
Q=P-\frac{P}{\sqrt{0.809+\left(\frac{P}{E P_{i}}\right)^{2}}}(\mathrm{~mm})
$$

and

$$
Q=P \cdot\left(1-\frac{E P_{i}}{\sqrt{0.809 . E P_{i}^{2}+P^{2}}}\right)(\mathrm{mm})
$$

The potential evaporation index EPi was calculated using the relation:

$$
E P_{i S R}=260.822+37.920 \bar{T}+0.077 \overline{T^{3}}
$$

where $\bar{T}$ - mean long-term annual temperature in the watershed $\left({ }^{\circ} \mathrm{C}\right)$

The values of the mean long-term annual precipitation depth $\mathrm{P}(\mathrm{mm})$ and the mean long-term annual temperature $\bar{T}\left({ }^{\circ} \mathrm{C}\right)$ for all of the analyzed watersheds were derived from the data measured at 8 meteorological stations of the High Tatras (Table 2), Figures (2) and (3).
Table 2. Mean annual precipitation and temperature in the High Tatras stations

\begin{tabular}{|l|c|c|c|}
\hline \multicolumn{1}{|c|}{ Station } & SA & $\mathrm{P}$ & $\mathrm{T}$ \\
\hline Tatranská Lomnica & 832 & 833 & 5.2 \\
\hline Starý Smokovec & 1018 & 930 & 4.9 \\
\hline Vyšné Hágy & 1140 & 864 & 4.3 \\
\hline Hrebienok & 1285 & 1132 & 3.5 \\
\hline Štrbské pleso & 1360 & 976 & 3.6 \\
\hline Popradské pleso & 1530 & 1319 & 2.2 \\
\hline Skalnaté pleso & 1778 & 1380 & 1.6 \\
\hline Lomnický štít & 2634 & 1855 & -3.7 \\
\hline
\end{tabular}

Explanatory notes: SA station altitude [m a. s. 1. ], $\mathrm{P}$ - long-term annual precipitation [mm], T - long-term annual temperature $\left[{ }^{\circ} \mathrm{C}\right]$

Using the results of equations (4), (6), (7) and (8), respectively, the coefficient $\mathrm{QA}_{\mathrm{w}}$ as: $Q A_{w}=\left(Q \cdot A_{w}\right) \cdot 1000^{-1}$ was calculated. Hydrological characteristics of reference watersheds are shown in Table 3.

\section{RESULTS AND DISCUSSION}

The analyses showed a strong correlation between the coefficient $\mathrm{QA}_{\mathrm{w}}$ and the bankfull geometric characteristics of the torrents' natural cross-sections: the width of the bed inside the banks $\mathrm{B}_{\mathrm{bf}}(\mathrm{m})$, the mean depth of the bed $\mathrm{H}_{\mathrm{bf}}(\mathrm{m})$, the channel cross-section area $\mathrm{A}_{\mathrm{bf}}\left(\mathrm{m}^{2}\right)$ and hydraulic characteristic - the bankfull discharge $\mathrm{Q}_{\mathrm{bf}}$ $\left(\mathrm{m}^{3} \cdot \mathrm{s}^{-1}\right)$. The results were tested by the t-test and the Shapiro-Wilk test. The determination coefficient $\left(\mathrm{R}^{2}\right)$ for the relationships without the asymptote ranged between $\mathrm{R}^{2}=0.921$ and $\mathrm{R}^{2}=0.968$; $\mathrm{p}$ - values from the Shapiro - Wilk test ranged between $p=0.0080$ and $p=0.5379$. The determination coefficient $\left(\mathrm{R}^{2}\right)$ for the relationships

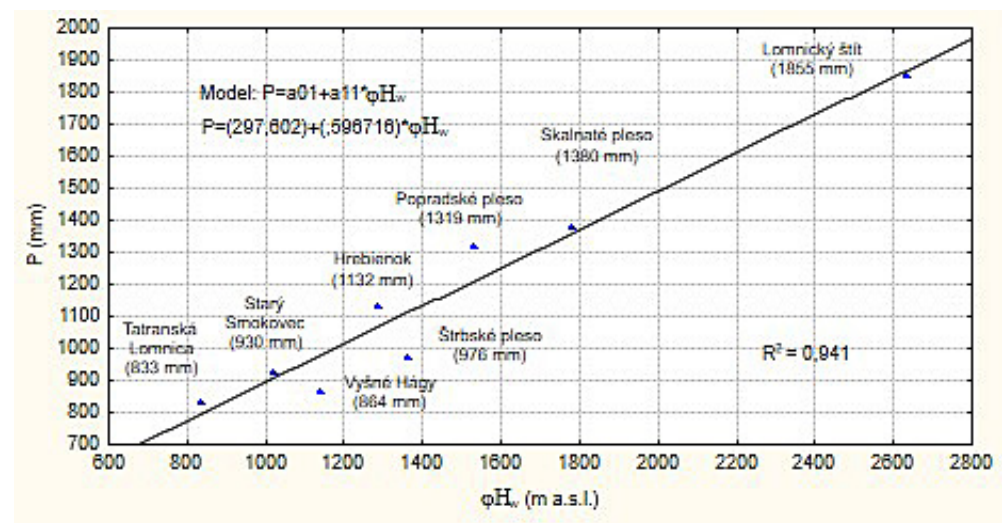

Figure 2. Relation between $\varphi \mathrm{H}_{\mathrm{w}}$ and the mean annual precipitation depth $\mathrm{P}$ 


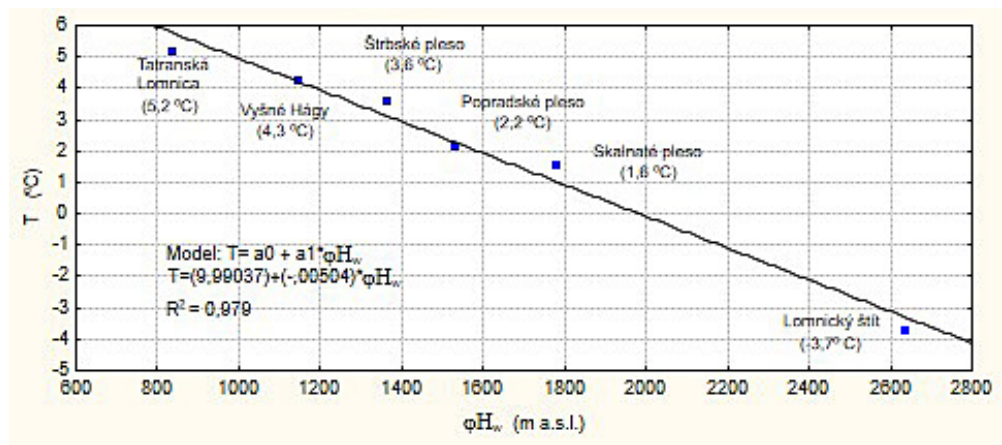

Figure 3. Relation between $\varphi \mathrm{H}_{w}$ and the mean annual temperature $\mathrm{T}$

Table 3. Hydrological characteristics of experimental watersheds

\begin{tabular}{|c|c|c|c|c|c|c|c|c|}
\hline Torrent & $A_{w}$ & $\varphi \mathrm{H}_{w}$ & $\mathrm{P}$ & $T$ & $E P_{i}$ & Q & $E$ & $\mathrm{QA}_{w}$ \\
\hline Beliansky potok & 3.17 & 1614 & 1261 & 1.9 & 333.40 & 937 & 324 & 2.97 \\
\hline Tri studničky & 0.36 & 1278 & 1060 & 3.6 & 400.93 & 680 & 380 & 0.24 \\
\hline Mlyničná voda & 2.18 & 1544 & 1219 & 2.3 & 348.97 & 881 & 338 & 1.92 \\
\hline Jamský potok & 0.60 & 1407 & 1137 & 3.0 & 376.66 & 776 & 361 & 0.47 \\
\hline Važecký potok & 0.25 & 1350 & 1103 & 3.2 & 384.69 & 736 & 367 & 0.18 \\
\hline Biely Váh & 10.62 & 1812 & 1379 & 0.9 & 295.01 & 1089 & 290 & 11.57 \\
\hline Lieskovec & 1.57 & 1434 & 1153 & 2.8 & 368.69 & 799 & 354 & 1.25 \\
\hline Mlynica & 6.90 & 1740 & 1336 & 1.3 & 310.29 & 1032 & 304 & 7.12 \\
\hline Poprad & 19.34 & 1789 & 1365 & 1.0 & 298.82 & 1072 & 293 & 20.74 \\
\hline Vel'ký šum & 4.86 & 1548 & 1221 & 2.3 & 348.97 & 883 & 338 & 4.29 \\
\hline Malý šum & 3.07 & 1665 & 1291 & 1.7 & 325.66 & 973 & 318 & 2.99 \\
\hline Háganský potok & 0.71 & 1277 & 1060 & 3.6 & 400.93 & 680 & 380 & 0.48 \\
\hline Batizovský p. & 5.69 & 1696 & 1310 & 1.5 & 317.96 & 999 & 311 & 5.68 \\
\hline Hromadná voda & 3.25 & 1510 & 1199 & 2.4 & 352.89 & 858 & 341 & 2.79 \\
\hline Velický potok & 6.16 & 1736 & 1333 & 1.3 & 310.29 & 1029 & 304 & 6.34 \\
\hline Slavkovský p. & 5.31 & 1655 & 1285 & 1.7 & 325.66 & 967 & 318 & 5.13 \\
\hline Malý Štiavnik & 0.88 & 1273 & 1057 & 3.6 & 400.93 & 678 & 379 & 0.60 \\
\hline Vel'ký Jazyk & 1.19 & 1306 & 1077 & 3.5 & 396.84 & 700 & 377 & 0.83 \\
\hline Štiavnik & 1.64 & 1528 & 1209 & 2.4 & 352.89 & 868 & 341 & 1.42 \\
\hline Pät' prameňov & 0.98 & 1239 & 1037 & 3.8 & 409.14 & 651 & 386 & 0.64 \\
\hline Pod Hrebienkom & 2.73 & 1308 & 1078 & 3.5 & 396.84 & 701 & 377 & 1.91 \\
\hline Studený potok & 18.13 & 1793 & 1367 & 1.0 & 298.82 & 1074 & 293 & 19.47 \\
\hline Hlboký potok & 4.88 & 1304 & 1076 & 3.5 & 396.84 & 699 & 377 & 3.41 \\
\hline Skalnatý potok & 9.37 & 1506 & 1196 & 2.5 & 356.83 & 851 & 345 & 7.97 \\
\hline Kež. Biela voda & 18.29 & 1612 & 1259 & 1.9 & 333.40 & 935 & 324 & 17.10 \\
\hline Sedem pram. & 4.58 & 1241 & 1038 & 3.8 & 409.14 & 652 & 386 & 2.99 \\
\hline
\end{tabular}

Explanatory notes: $A_{w}-$ watershed area $\left[\mathrm{km}^{2}\right], \varphi \mathrm{H}_{w}-$ mean altitude of the watershed [m a. s. 1.], $\mathrm{P}-$ mean annual precipitation depth $[\mathrm{mm}], \mathrm{T}$ - mean annual temperature $\left[{ }^{\circ} \mathrm{C}\right], \mathrm{EPi}$ - potential evaporation index, $\mathrm{Q}-$ mean annual runoff depth $[\mathrm{mm}], \mathrm{E}-$ mean annual evapotranspiration depth [mm], QAw - coefficient calculated as (Q.Aw).1000-1

with asymptote ranged between $\mathrm{R}^{2}=0.953$ and $\mathrm{R}^{2}=0.970 ; \mathrm{p}$ - values from the Shapiro - Wilk test ranged between $\mathrm{p}=0.0016$ and $\mathrm{p}=0.8625$. Derived regional regression equations for analyzed correlation relations are listed in Tables 4 and 5 also contains the absolute and the regression coefficients for particular regional equations.
$\mathrm{S}_{\mathrm{r}}: \sqrt{\frac{1-\mathrm{R}^{2}}{\mathrm{n}-2}}, \mathrm{t}: \frac{\mathrm{R}}{\mathrm{S}_{\mathrm{r}}}$, RMSE: root mean square error, SWp: $\mathrm{p}$ - value by Shapiro-Wilk test

Table 5 contains the statistical characteristics and testing of particular relations. In all cases, the number of root mean standard errors using the equation with the asymptote, is lower than when 
Table 4. Regression regional equations by equations (2) and (3)'

\begin{tabular}{|c|c|}
\hline Correlation relation & Regression equation \\
\hline$B_{b f(1)}=f\left(Q A_{w}\right)$ & $\mathrm{B}_{\mathrm{bff}(1)}=1.5993^{*}\left(\mathrm{QA}_{\mathrm{w}}\right)^{0.6087}$ \\
\hline$H_{b f(1)}=f\left(Q A_{w}\right)$ & $\mathrm{H}_{\mathrm{b}(1)}=0.4162^{*}\left(\mathrm{QA}_{\mathrm{w}}\right)^{0.2949}$ \\
\hline$A_{b f(1)}=f\left(Q A_{w}\right)$ & $A_{b f(1)}=0.4135^{*}\left(Q A_{w}\right)^{0.9823}$ \\
\hline$Q_{b f(1)}=f\left(Q A_{w}\right)$ & $\mathrm{Q}_{\mathrm{bf}(1)}=0.6630^{*}\left(\mathrm{QA}_{\mathrm{w}}\right)^{1.2162}$ \\
\hline$B_{b f(2)}=f\left(Q A_{w}\right)$ & $B_{b f(2)}=1.7983^{*}\left(1-\operatorname{EXP}\left(-(2.1980)^{*} \mathrm{QA}_{w}\right)\right)+0.4262^{*} \mathrm{QA}_{\mathrm{w}}$ \\
\hline$H_{b f(2)}=f\left(Q A_{w}\right)$ & $\mathrm{H}_{\mathrm{bf}(2)}=0.4375^{*}\left(1-\operatorname{EXP}\left(-(4.6409)^{*} \mathrm{QA}_{\mathrm{w}}\right)\right)+0.0333^{*} \mathrm{QA} \mathrm{w}_{\mathrm{w}}$ \\
\hline$A_{b f(2)}=f\left(Q A_{w}\right)$ & $A_{b f(2)}=0.1935^{*}\left(1-\operatorname{EXP}\left(-(10.992)^{*} \mathrm{QA}_{w}\right)\right)+0.3779^{*} \mathrm{QA}_{w}$ \\
\hline$Q_{b f(2)}=f\left(Q A_{w}\right)$ & $Q_{b f(2)}=-61.642^{*}\left(1-E X P\left(-(0.0306)^{*} \mathrm{QA}_{w}\right)\right)+2.6885^{\star} \mathrm{QA}_{w}$ \\
\hline
\end{tabular}

Explanatory notes: $\mathrm{B}_{\mathrm{bf}(1)}, \mathrm{H}_{\mathrm{bf}(1)}, \mathrm{A}_{\mathrm{bf}(1)}, \mathrm{Q}_{\mathrm{bf}(1)}$ - characteristics calculated by equation (2) without the asymptote, $\mathrm{B}_{\mathrm{bf}(2)}, \mathrm{H}_{\mathrm{bf}(2)}, \mathrm{A}_{\mathrm{bf}(2)}, \mathrm{Q}_{\mathrm{bf}(2)}$ - characteristics calculated by equation (3) with the asymptote

the equation without the asymptote was used. The graphic representation of the regional curves are shown in Figures. (4) - (7).

The graphic presentation of residuals for each relations of the Shapiro-Wilk test are shown in Figures. (8) - (15). Based on our analysis, we recommend the use of the regression equation (3) with theasymptote to determine regional equations of hydraulic geometry.

In relation to bankfull geometric and hydraulic characteristics, coefficient $\mathrm{QA}_{\mathrm{w}}$ was evaluated for the first time in the SR [Jakubis, 2008] in geomorphological unit Pol'ana (Central Slovakia, neovolcanites) in 25 torrents with characteristics with the medians $\mathrm{A}_{\mathrm{w}}=4.47\left(\mathrm{~km}^{2}\right)$, $\mathrm{B}_{\mathrm{bf}}=2.40(\mathrm{~m}), \mathrm{H}_{\mathrm{bf}}=0.55(\mathrm{~m}), \mathrm{A}_{\mathrm{bf}}=1.05\left(\mathrm{~m}^{2}\right)$, $\mathrm{Q}_{\mathrm{bf}}=1.14\left(\mathrm{~m}^{3} \cdot \mathrm{s}^{-1}\right)$. The determination coefficients in these relationships ranged between $\mathrm{R}^{2}=0.907$ and $\mathrm{R}^{2}=0.989$. Author [Pšida, 2014] evaluated the relationships between the QA coefficient and the-above mentioned bankfull characteristics of four torrents in four different geographic regions - geomorphological units in the SR with different bedrocks with characteristics with the medians $\mathrm{A}_{\mathrm{w}}=18.81\left(\mathrm{~km}^{2}\right)$, $\mathrm{B}_{\mathrm{bf}}=8.10 \mathrm{~m}, \mathrm{H}_{\mathrm{bf}}=0.83(\mathrm{~m}), \mathrm{A}_{\mathrm{bf}}=4.53\left(\mathrm{~m}^{2}\right)$,
$\mathrm{Q}_{\mathrm{bf}}=8.02\left(\mathrm{~m}^{3} \cdot \mathrm{s}^{-1}\right)$. The determination coefficients ranged between $\mathrm{R}^{2}=0.705$ and $\mathrm{R}^{2}=0.960$. Both authors confirmed varying and specific natural geometric and hydraulic characteristics of torrent beds and their long - term morphogenesis in watersheds with different bedrocks.

\section{CONCLUSION}

The torrents are often located in protected areas. Therefore, a very sensitive approach to interfering with the torrent, flood and erosion control is needed. If such principles are not respected, various errors in torrent control designing and revitalization may occur, with negative ecological and environmental consequences in the landscape. Derived regional equations and curves make it possible to come up with a valuable input to the ecological designing and dimensioning in torrent control, flood and erosion control and torrent revitalization in the areas from which they were derived and, at the same time, to the gradual creation of hydrologic landscape regions. The results of research in regional hydraulic geometry provides these options.

Table 5. Statistic characteristics and testing of analyzed relations

\begin{tabular}{|c|c|c|c|c|c|c|c|c|}
\hline Correlation relation & $\mathrm{R}$ & $\mathrm{R}^{2}$ & $\mathrm{~S}_{\mathrm{R}}$ & $\mathrm{t}$ & $>=<$ & $\mathrm{t}_{0.01(24)}$ & RMSE & $\mathrm{SWp}$ \\
\hline $\mathrm{B}_{\mathrm{bf}(1)}=\mathrm{f}\left(\mathrm{QA}_{\mathrm{w}}\right)$ & 0.980 & 0.960 & 0.0408 & 24.02 & $>$ & 2.797 & 0.55 & 0.2177 \\
\hline $\mathrm{H}_{\mathrm{bf}(1)}=\mathrm{f}\left(\mathrm{QA}_{\mathrm{w}}\right)$ & 0.959 & 0.921 & 0.0574 & 16.71 & $>$ & 2.797 & 0.06 & 0.1551 \\
\hline $\mathrm{A}_{\mathrm{bf}(1)}=\mathrm{f}\left(\mathrm{QA}_{\mathrm{w}}\right)$ & 0.983 & 0.966 & 0.0376 & 26.14 & $>$ & 2.797 & 0.43 & 0.5379 \\
\hline $\mathrm{Q}_{\mathrm{bf}(1)}=\mathrm{f}\left(\mathrm{QA}_{\mathrm{w}}\right)$ & 0.984 & 0.968 & 0.0365 & 26.96 & $>$ & 2.797 & 1.38 & 0.0080 \\
\hline $\mathrm{B}_{\mathrm{bf}(2)}=\mathrm{f}\left(\mathrm{QA}_{\mathrm{w}}\right)$ & 0.984 & 0.968 & 0.0365 & 26.96 & $>$ & 2.797 & 0.51 & 0.6974 \\
\hline $\mathrm{H}_{\mathrm{bf}(2)}=\mathrm{f}\left(\mathrm{QA}_{\mathrm{w}}\right)$ & 0.976 & 0.953 & 0.0443 & 22.03 & $>$ & 2.797 & 0.05 & 0.8625 \\
\hline $\mathrm{A}_{\mathrm{bf(2)}}=\mathrm{f}\left(\mathrm{QA}_{\mathrm{w}}\right)$ & 0.985 & 0.970 & 0.0353 & 27.9 & $>$ & 2.797 & 0.41 & 0.7569 \\
\hline $\mathrm{Q}_{\mathrm{bf}(2)}=\mathrm{f}\left(\mathrm{QA}_{\mathrm{w}}\right)$ & 0.985 & 0.969 & 0.0359 & 27.44 & $>$ & 2.797 & 1.37 & 0.0016 \\
\hline
\end{tabular}

Explanatory notes: $\mathrm{R}$ - index of correlation, $\mathrm{R}^{2}$ - index of determination, 


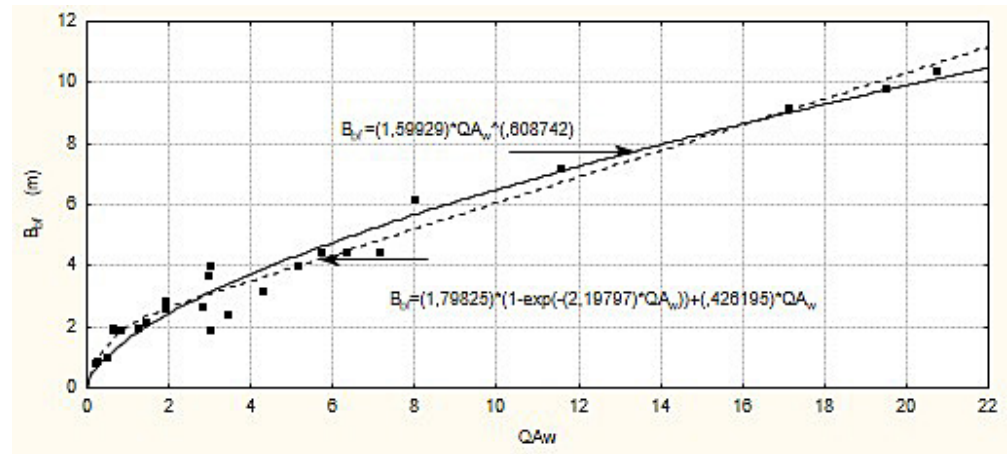

Figure 4. Relation between $\mathrm{QAw}$ and $\mathrm{B}_{\mathrm{bf}}$

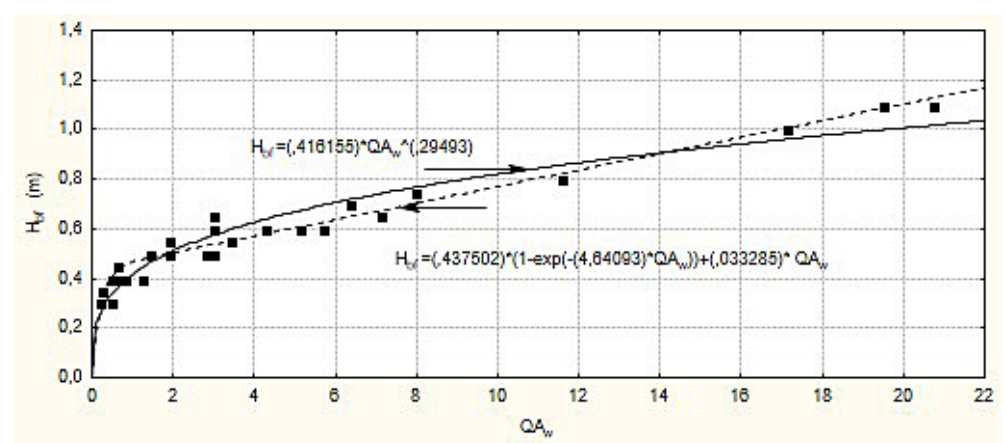

Figure 5. Relation between $\mathrm{QAw}$ and $\mathrm{H}_{\mathrm{bf}}$

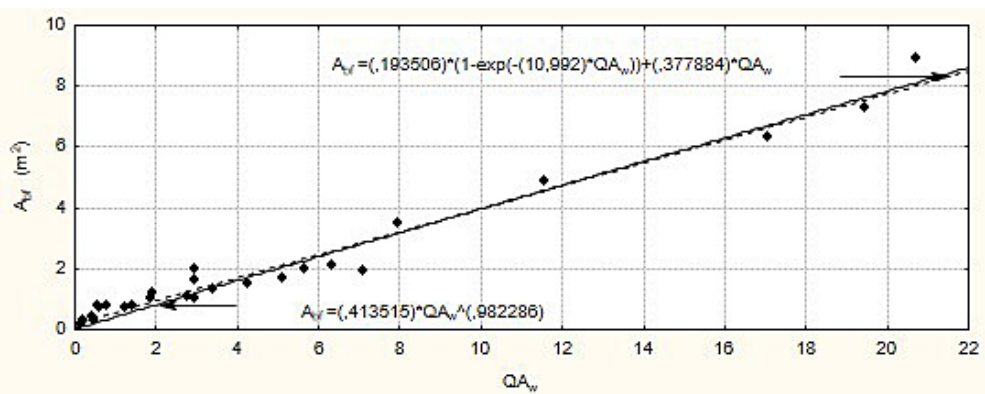

Figure 6. Relation between $\mathrm{QAw}$ and $\mathrm{A}_{\mathrm{bf}}$

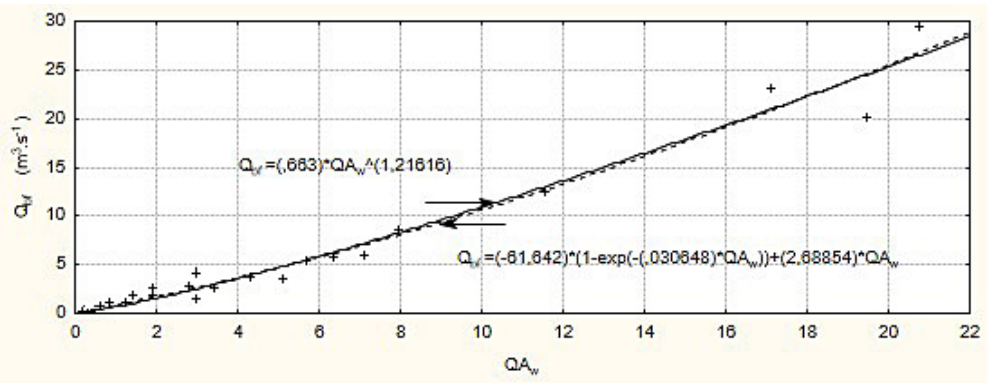

Figure 7. Relation between $\mathrm{QAw}$ and $\mathrm{Q}_{\mathrm{bf}}$ 


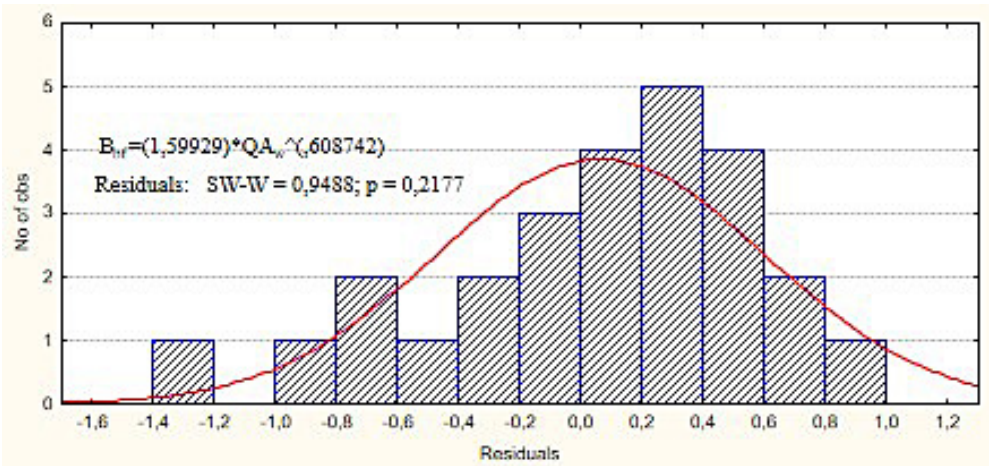

Figure 8. Residuals for the relation $B_{b f}=f(Q A w)$ by equation (2)

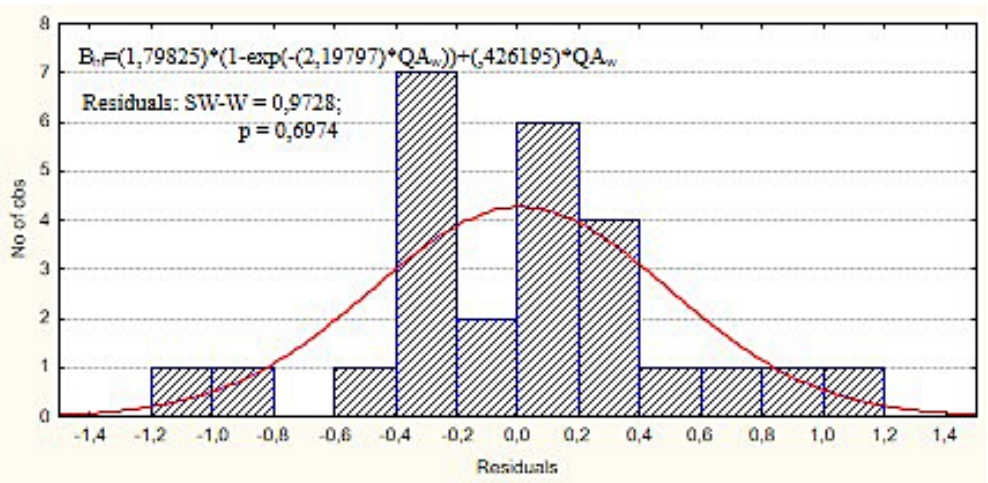

Figure 9. Residuals for the relation $B_{b f}=f(Q A w)$ by equation (3)

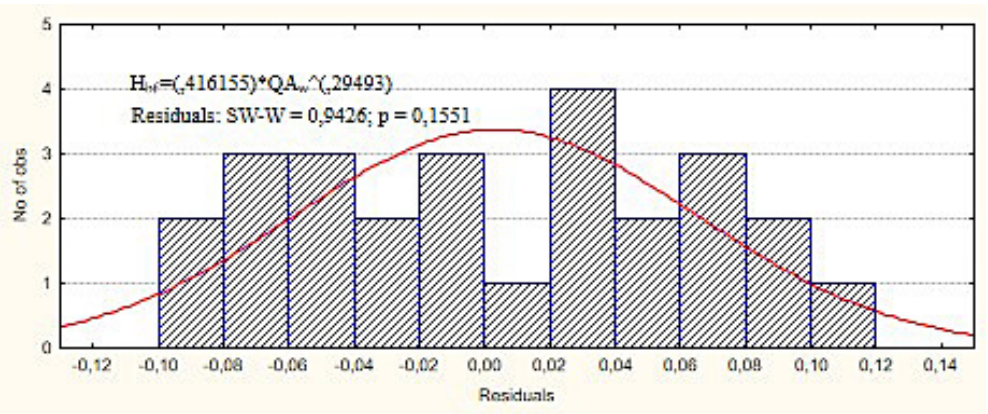

Figure 10. Residuals for the relation $\mathrm{H}_{\mathrm{bf}}=\mathrm{f}(\mathrm{QAw})$ by equation (2)

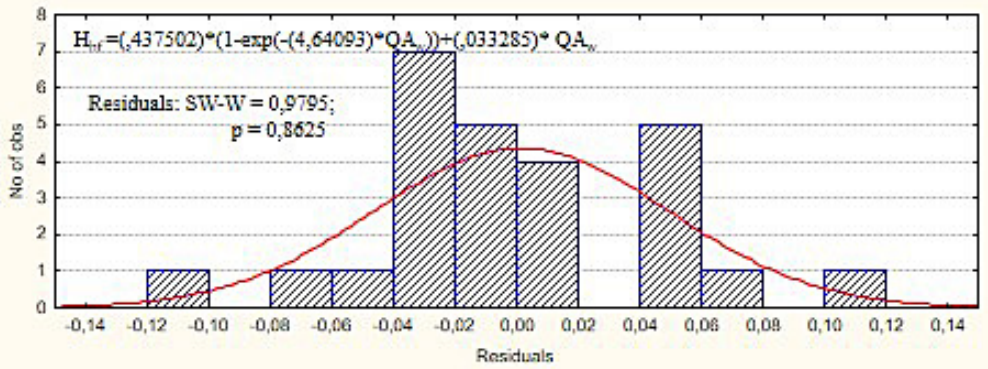

Figure 11. Residuals for the relation $\mathrm{H}_{\mathrm{bf}}=\mathrm{f}(\mathrm{QAw})$ by equation (3) 


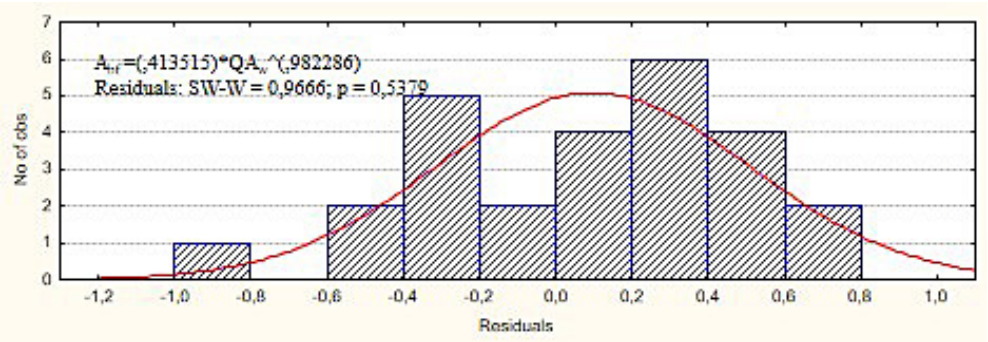

Figure 12. Residuals for the relation $A_{b f}=f(Q A w)$ by equation (2)

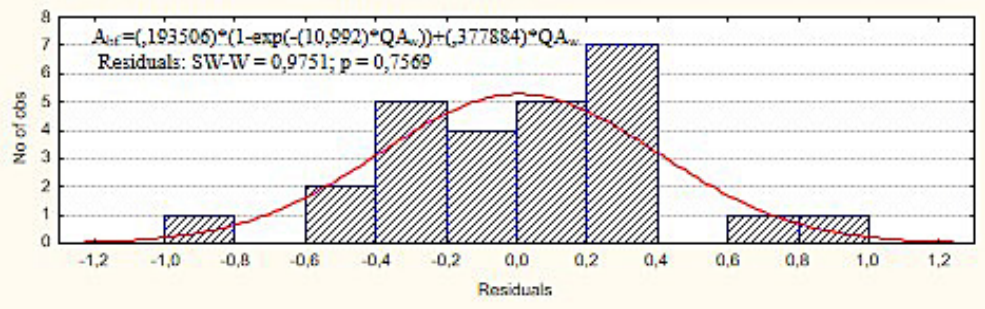

Figure 13. Residuals for the relation $A_{b f}=f(Q A w)$ by equation (3)

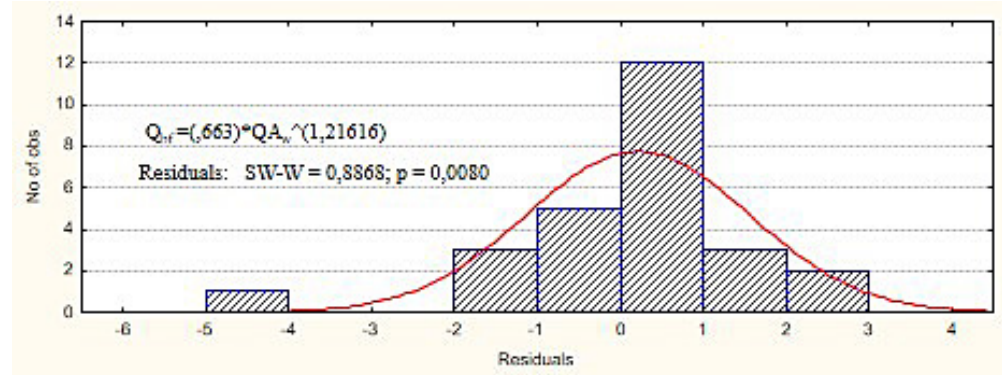

Figure 14. Residuals for the relation $\mathrm{Q}_{\mathrm{bf}}=\mathrm{f}(\mathrm{QAw})$ by equation (2)

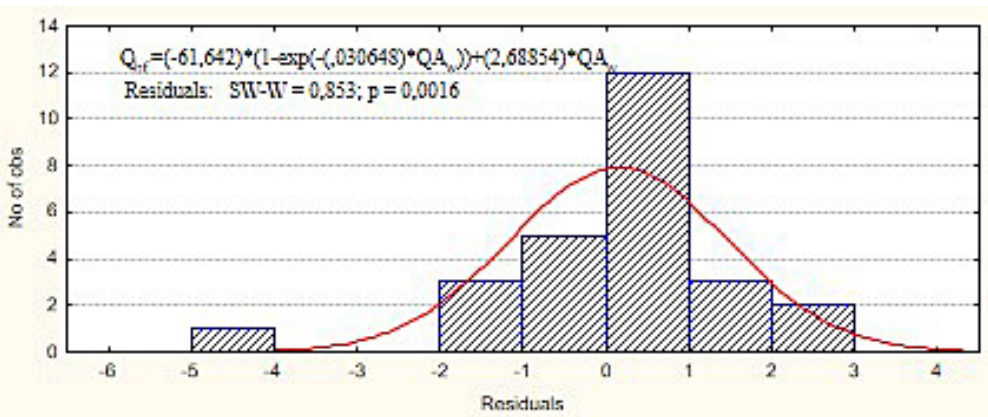

Figure 15. Residuals for the relation $\mathrm{Q}_{\mathrm{bf}}=\mathrm{f}$ (QAw) by equation (3)

\section{Acknowledgements}

This article was supported by the Grant Agency KEGA of the Ministry of Education, Science, Research and Sport of the Slovak Republic within the project No. 006TU Z-4/2018: 3-D functional models of landscape flood protection objects as a new methods and forms of university education.

\section{REFERENCES}

1. Blackburn-Lynch, W., Agouridis, C. T. and Barton, CH. D. 2017. Development of Regional Curves for Hydrologic Landscape Regions (HLR) in the United States. Journal of the American Water Resources Association, 53, 903-928.

2. Bieger, K. H., Rathjens, H., Allen, P. M. and Ar- 
nold, J. G. 2015. Development and evaluation og bankfull hydraulic geometry relationships for the physiographic regions of the United States. Journal of the American Water Resources Association, 51, 842-858.

3. Composite Authors 2002. Landscape Atlas of the Slovak Republic [In Slovak: Atlas krajiny Slovenskej republiky]. Bratislava: Ministry of Environment of the SR, Banská Štiavnica: Esprit.

4. Gallart, F., Llorens, P., Latron, J. and Regüés, D. 2002. Hydrological processes and their seasonal controls in a small Mediteranean mountain catchment in the Pyrenees. Hydrology and Earth System Science Discussions, European Geoscience Union, 6(3), 527-537.

5. Han, S., Xu, D. and Wang, S. 2012. Runoff formation from experimental plot, field, to small catchment scales in agricultural North Huaihe River Plain, China. Hydrol. Earth Syst. Sci., 16: 3115-3125.

6. Hrnčíŕ, M., Šanda, M., Kulasová, A. and Císlerová, M. 2010. Runoff formation in small catchment at hillslope and catchment scale. Hydrological processes, 24, 2248-2256.

7. Howell, S. 2009. Development of Regional Hydraulic Geometry Curves for the Santa Cruz Mountains. San Luis Obispo: Natural Resources Management Department of California Polytechnic State University.

8. Jakubis, M. 2008. The research of dependencies of regional hydraulic geometry on the example of water flows of Protected Landscape Area - Biosphere Reserve Pol'ana [In Slovak: Výskum závislostí regionálnej hydraulickej geometrie na príklade vodných tokov CHKO BR Pol'ana]. Zvolen: Technical University in Zvolen.

9. Leopold, L. B., Wolmann, M. G. and Miller, J. P. 1992. Fluvial Processes in Geomorphology. New York: Dover Publications Inc.

10. Lehotský, M. and Novotný, J. 2004. Morphological zones of watercourses of Slovak Republic [Morfologické zóny vodných tokov Slovenska]. Geomorphologia Slovaca, IV, 48-53.

11. Osati, K., Nayyeri, H. and Osmani, P. 2016. Efficiency of power regresion model for bankfull hydraulic geometry in stable canals (Case study: Tarwal basin).
Iran-Water Resources Research, 12(3), 189-200.

12. Page, K. J. 1988. Bankfull discharge frequency for the Murrumbidgee River, New South Wales. In: Warner, R. F. [ed.], Fluvial geomorphology of Australia. Sydney, Academic Press: 267-281.

13. Parker, G. 2010. The Gravel River Bankfull Discharge Estimator. Minneapolis: University of Minnesota, National Center for Earth-surface Dynamics.

14. Schumm, S. A. 1977. The Fluvial System. New York, John Wiley \& Sons.

15. Powel, R. O., Miller, S. J., Westergard, B. E., Mulvihill, CH. I., Baldigo, B. P., Gallagmer, A. S., and Starr, R. R. 2004. Guidelines for Surveying Bankfull Channel Geometry and Developing Regional Hydraulic - Geometry Relations for Streams of New York State. U. S. Geological Survey Open File Report 03-92. New York: Troy

16. Pšida, J. 2014. The research of regional hydraulic geometry of torrent channels in selected geomorphologic units of the SR [In Slovak: Výskum regionálnej hydraulickej geometrie bystrinných korýt vo vybraných geomorfologických celkoch SR]. [Ph.D. Thesis.] Zvolen, Technical University in Zvolen, Faculty of Forestry.

17. Rosgen, D. and Silvey, H. L. 1996. Applied River Morphology. Pagosa Spring: Wildland Hydrology.

18. Szolgay J., Hlavčová K., Parajka J. and Čunderlík J. 1997. An Influence of Climate Change on Runoff Regime in Slovakia [In Slovak: Vplyv klimatickej zmeny na odtokový režim na Slovensku]. Bratislava: Ministry of Environment of the SR, Bratislava: Slovak Hydrometeorological Institute, 11-108.

19. Tani, M. 1997. Runoff generation processes estimated from hydrological observations on a step forested hillslope with a thin soil layer. Journal of Hydrology, 200(1-4), 84-109.

20. Wilkerson, G. V. 2009. Improved Bankfull discharge prediction using 2-year Recurrence Period Discharge. Journal of American Ressources Association, 44, 243-258.

21. Wolock, D. M., Winter, T. C. and Mc. Mahon, G. 2004. Delineation and Evaluation of Hydrologic Landscape Regions in the United States using GIS Tools and Multivariate Statistical Analyses. Environmental Management, 34, 71-88. 